\title{
Ireland: The Model EU Citizen? Explaining Irish Attitudes towards the EU
}

\author{
Dr Kathryn Simpson \\ Senior Lecturer (Associate Professor) in Political Economy \\ Manchester Metropolitan University
}

\section{Ireland and the EU: 'Good Europeans' with a Pro-integrationist Attitude}

The Republic of Ireland is often regarded as one of the most enthusiastic supporters of European integration since it's accession to the EU along with the UK and Denmark in the first wave of EU enlargement in 1973. Ireland is often considered an EU member state of 'good Europeans' with a pro-integrationist attitude. Eurobarometer data from 1973 - 2016 illustrates this with Irish respondents showing consistent and positive support towards the EU (See Figure 1).

\section{<<Figure 1 About Here>>}

However, the reality of Irish public opinion is more nuanced: support for the EU in Ireland is not a single entity but a complex set of opinions determined by a variety of factors. Since the 1990's knowledge about the EU amongst the Irish public is low with individuals in Ireland more likely to refer to the economic aspects of the EU, such as the freedom of movement, the Euro and economic prosperity. This 'knowledge deficit' is perhaps unsurprising as for the first twenty years of EU membership Ireland's self-perception of its status within the EU was that of a small peripheral member state. Ireland became a net beneficiary of EU funding and successive Irish governments and negotiators prioritized and maximized receipts of EU funding via the Common Agricultural Policy (CAP) or European Regional Structural and Development Funds (ERSDF). Ireland was often considered to be suffering from a 'sponger syndrome' in viewing the EU as a source of additional exchequer funding for a poor EU member state with Irish politicians and officials possessing a 'begging bowl' mentality. During the 1990's Irish government and Irish society were indeed proEuropean however support for the European integration process itself was conditional Ireland's approach was to ask what Brussels could do for the Irish economy, rather than what the Irish economy could do for Brussels. 
Ireland - a Staunchly Pro-European Member State?

The pro-EU status of the Irish began to be challenged in the 2000s when Ireland's economic boom led the Irish government into conflict with the EU over its management of the Irish economy. The Irish government was criticized for its refusal to dampen the successful Celtic Tiger economy and for its substantial tax concessions for foreign investors which were (and still are) regarded by the European Commission as breaking the spirit if not law of the European Single Market. By the early to mid 2000s, the continued deepening of the processes of European integration and the introduction of the Euro met little resistance and in fact produced sources of identity for many. However, individuals in Ireland tend to focus on national or intergovernmental aspects of EU membership and representation rather than on the policy-making aspects of EU institutions which produce legislation that has an effect across all EU member states. Therefore, there remains a proportion of the population who oppose further 'sharing of sovereignty' and are concerned about the impact and Ireland's involvement in the EU is having on Irish identity, values and culture. As a consequence, the EU project in Ireland is not one which can be encapsulated by a single overarching judgement but only through the appreciation of many different facets. These nuances and the multifaceted nature of Irish public opinion towards the EU were borne out in the rejection of the Nice Treaty in May 2001 and the Lisbon Treaty in June 2008.

\section{The Complex Nature of Referendums as Forums of Debate on the EU}

Between 1972-2012, Irish governments have held nine European referendum campaigns with two broad characteristics emerging from each campaign. Firstly, turnout in EU-related referendums is generally lower than at Irish general elections with the lowest turnout being 34.79\% in the first referendum on the Nice Treaty in 2001 (see Table 1). Secondly, EU-related treaties (with the exception of the Accession Treaty in 1973) have gained broad support across the political establishment including the mainstream political parties, trade unions and business organizations. Political parties such as Sinn Fein and the Green Party as well as non-party political and civil society groups have all opposed EU-related referendums. Up until the first referendum on the Treaty of Nice in 2001, successive Irish governments and pro-European campaigners pointed to the benefits EU membership had brought to Ireland in terms of direct financial transfers and increased opportunities for Irish workers and Irish industry. Pro-European groups and political parties in Ireland have 
consistently relied upon the permissive consensus and the fact that individuals in Ireland appreciated the considerable benefits Ireland derived from EU membership thus little effort was made to explain the issues at stake for the Irish electorate.

$<<$ Table 1 About Here>>

The rejection of the Nice Treaty in 2001 and Lisbon Treaty in 2008 highlighted the potential emergence of a new popular scepticism towards the EU in so far as it concerns Irish interests and deeper European integration in Ireland. The emergence of referendums as key forums for debate about the EU in Ireland has resulted in a much greater degree of polarisation of opinions. This polarisation is two-fold. Firstly, referendums tend to reduce complex issues to a simple 'Yes' or 'No' answer. Secondly, with nine EU-related being held thus far in Ireland this mechanism of direct democracy has fuelled an element of disenchantment among the Irish electorate with voters questioning why they are continuously being asked to vote on complex EU issues.

Voting in EU related referendums can be distinguished between 'second order' effects and the impact of 'issue voting'. The 'second order' effects approach infers that the central determinant of vote choice in EU-related referendums is an EU member states national party politics and that voters often use referendums in order to express their discontent or satisfaction with the incumbent government as well as determining their vote as a result of party cues with people voting in accordance with their political party affiliation. While according to the 'issue voting' approach, voting in EU related referendums is driven by individuals' EU-related concerns i.e. people decide to support, or not support, a treaty based on the merits of the European project and the specific elements that particular treaty poses to them.

When the Irish electorate voted 'No' to the Nice Treaty in May 2001 and the Lisbon Treaty in June 2008 both the domestic political and economic context played a vital role highlighting elements of the 'second order' and 'issue voting' approaches. In the first Nice Treaty referendum three key issues were at stake: sovereignty, neutrality and EU 
enlargement emphasising 'issue voting' by the electorate ${ }^{1}$. In the first referendum on the Lisbon Treaty 'second-order' factors can be cast aside as satisfaction with the Irish government declined significantly between Lisbon 1 and Lisbon 2 . The change in the political context from the first Lisbon Treaty referendum in June 2008 to the second Lisbon Treaty referendum in October 2009 was a result of the Irish Government's attempts to address concerns highlighted by the 'No' campaign on issues in relation to military neutrality, the corporation tax rate, the belief that abortion services would be widely available, a weakening of workers' rights and a reduction in Irish influence at the EU-level due to the loss of a permanent Irish EU Commissioner ${ }^{2}$. However, it was perhaps the change in economic context from Lisbon 1 to Lisbon 2 which was most dramatic as Ireland plunged into recession after the rejection of the first referendum on the Lisbon Treaty. It was frequently expressed that as a result of the onset of the economic and financial crisis Ireland was safer as part of a larger economic community that could potentially offer Ireland protection, which Ireland did receive through a three-year Economic Adjustment Programme or Bailout in December 2010 from the Troika (which it exited in December 2013). Yet despite the emergence of a potential popular scepticism from 2001-2008 and the financial bailout received in 2010, Irish attitudes towards the EU continued to remain consistently positive (see Figure 1) with Eurobarometer from 2009 - 2014 demonstrating that the Irish electorate maintained that the EU was the best placed institution to take effective action against the economic and financial crisis (See Figure 2).

\section{<<Figure 2 About Here >}

\section{Ireland and Brexit: a potential Irexit?}

Brexit however represents the single greatest political and economic challenge to Ireland since World War Two. Ireland's unique circumstances, including the issue of peace in Northern Ireland and the preservation of the Good Friday Agreement (GFA), must be addressed in Brexit negotiations. Firstly, the future trade relationship between the EU and the UK will be crucial to both constituent parts of the island of Ireland. Secondly, the

\footnotetext{
${ }^{1}$ The Irish Government sought Declarations with the EU which were added to the Nice Treaty at an EU Summit in Seville in June 2002 which provided protection for the continuation of Irish neutrality

${ }^{2}$ Guarantees on these issues were added as Protocols in the second referendum on the Lisbon Treaty
} 
relationship, whether it is the result of EU-UK relations, or a relationship specifically designed to address Ireland's circumstances, does not solely depend on the nature of the border between Northern Ireland and the Republic of Ireland, and no border, whether it is visible or invisible, can create a satisfactory result if the economic arrangements are unsound. Hence, why the Irish government has advocated for the UK, or at a minimum Northern Ireland, to remain in the European Single Market and the Customs Union.

This has resulted in fraught relations between Dublin, London and Belfast which came to the fore in December 2017 as Phase One of Brexit negotiations came to a close. These talks are officially between the EU and the UK delegations, but an Irish delegation has formed part of these negotiations as the issue of the border between the Republic of Ireland and Northern Ireland became all the more pertinent. These intense bilateral talks between British and Irish officials on the border question led to a breakthrough swapping a pledge for "no regulatory divergence" in the text for a promise of "regulatory alignment". For Britain, "alignment" was regarded as weaker than "no divergence", while for the Republic of Ireland, it was understood to mean that Britain had made a promise that there would be no hard border - which implied a special status for Northern Ireland. But for Northern Ireland's Democratic Unionist Party (DUP), a political party that defends the Union with the UK and provides the current Conservative Party with its majority in government under a Confidence and Supply Agreement, this is problematic. The DUP campaigned for Brexit and has insisted that Northern Ireland will leave the EU on the same terms as the rest of the UK in March 2019. What the December impasse highlighted was that politics trumps economics and as a consequence this has an impact on a possible Irexit - or Irish exit of the EU - debate.

The anticipation of the effect of Brexit on the Irish economy has learned itself to speculation about a potential Irexit. The question of Irexit has developed primarily as an economic argument implying that Ireland will be left marginalised, peripheral and dependent post Brexit. This economic reasoning centres upon two issues. Firstly, Ireland's participation in the European Single Market is vital to the economy and secondly, Ireland's interactions with the British economy are heavily intertwined. However, there are three fundamental economic and political problems with the Irexit thesis. Firstly, from an economic perspective, the stance on a possible Irexit omits the question of how Ireland developed economic independence and moved on from political domination by the UK when it joined the EU in 1973. Irish accession to the EU enabled the diversification in trade and investment, including 
the European Single Market, but also attracting Foreign Direct Investment (FDI) from the USA. Secondly, from a political perspective, the equal partnership between the UK and Ireland as EU member states facilitated negotiations on the issue of peace in Northern Ireland and in particular the Good Friday Agreement. Thirdly, public opinion support for the EU in Ireland is consistently positive and there is little appetite among individuals in Ireland to leave the EU. A poll conducted by the political polling company RED C in May 2017 found that $88 \%$ of individuals in Ireland believe that Ireland should remain in the EU, notwithstanding Brexit. This trend is reiterated by Eurobarometer data for 2017 with $83 \%$ of individuals in Ireland believing membership of the EU is a good thing (see Figure 1). Overall, the Irexit debate is a crude caricature of Ireland's political and economic situation which falls back on inherent clichés (i.e. Ireland is a small, peripheral member state, reliance on the UK etc.), disregarding Ireland's success in Brexit negotiations (i.e. ensuring the UK cannot move forward to trade negotiations until the unique Irish issues have been full addressed) and provides no indication of what Irexit and the future relationship with the EU would look like. But perhaps more importantly, it demonstrates a rudimentary understanding of Irish attitudes towards the EU. An Irexit is highly questionable.

\section{What next for Ireland?}

While an Irexit is unlikely, Ireland's relationship with the EU will not be without difficulties. Firstly, in the context of Brexit on issues such as the economic impact Ireland will experience as well as questions in relation to the border between Northern Ireland and the Republic of Ireland. Secondly, in the context of the future relationship with the EU most notably the Apple tax ruling and the subsequent referral to the European Court of Justice. Although a knowledge deficit continues to exists among the public in Ireland the salience of EU membership and support for the EU is consistently strong and shows little sign of abating. Brexit has forced Ireland to think anew about its relationship with both the UK and the EU and instead of turning towards an historical periphery Ireland recognizes that present day challenges are global and do not respect borders. As a consequence, Ireland is best placed to meet these challenges through continued cooperation and engagement subsequently influencing solutions as part of the EU. Brexit means Brexit but for Ireland remaining a member state of the EU is in its national interest - and public opinion recognizes this. 


\section{List of Figures and Tables}

\section{Figures}

Figure 1: Support for the EU in Ireland 1973-2017

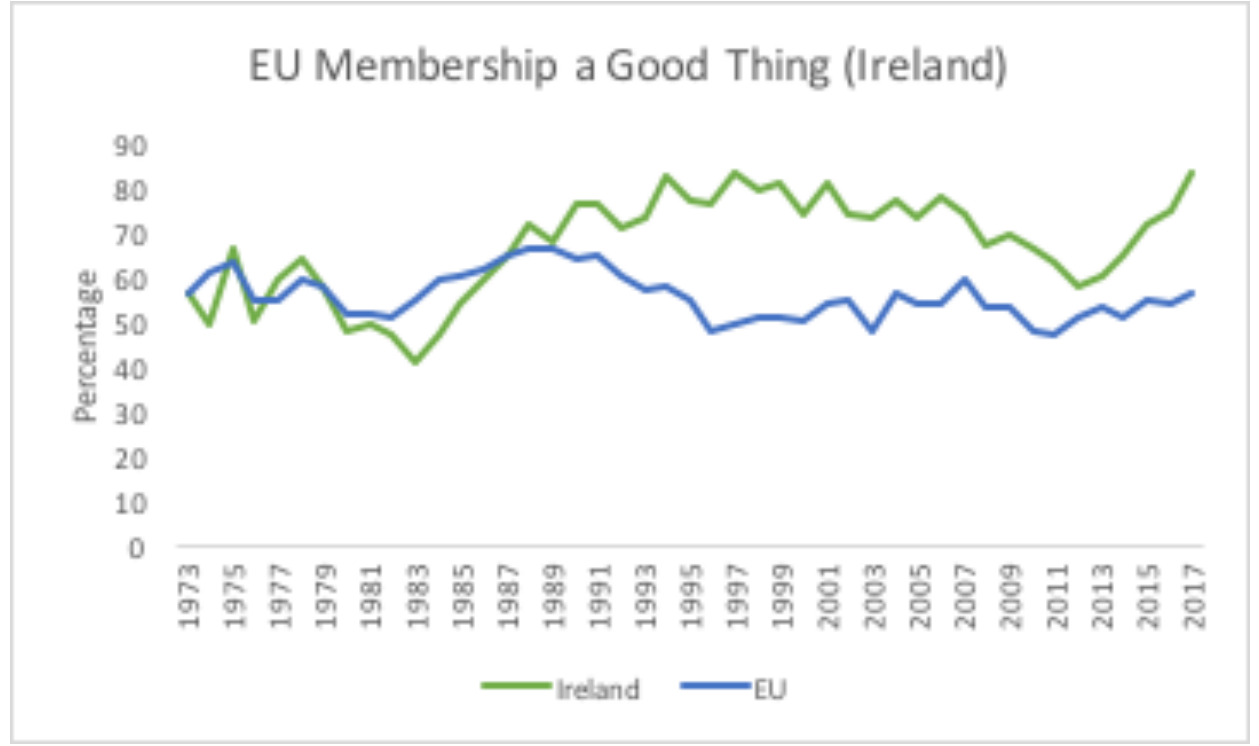

Source: Standard Eurobarometer Data 1973-2017

Figure 2: Effective action against the economic \& financial crisis 2009-2014

Effective Action Against Effects of Economic \& Financial Crisis 20092014

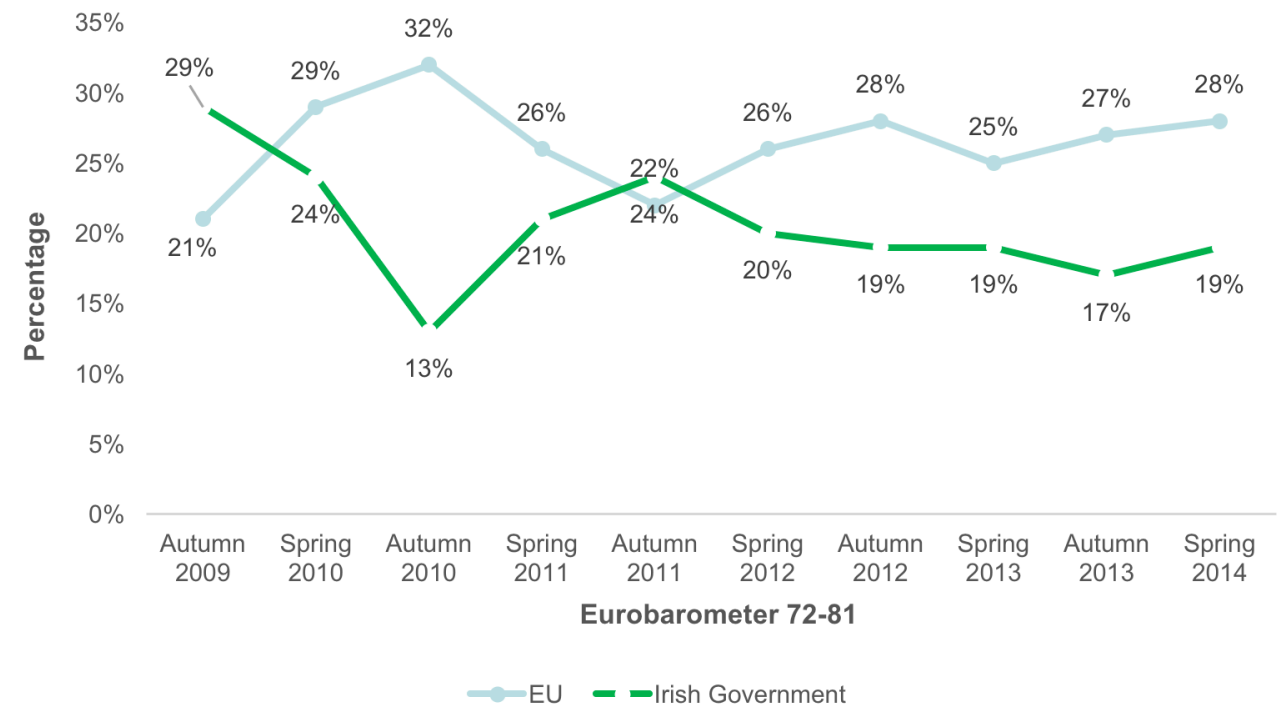




\section{Tables}

Table 1: EU-Related Referendums in Ireland 1973 - 2012

\begin{tabular}{|c|c|c|}
\hline EU-Related Treaty & Date, Month, Year & Result (incl. turnout) \\
\hline $\begin{array}{l}\text { Accession to the European } \\
\text { Community }\end{array}$ & $10^{\text {th }}$ May 1973 & $\begin{array}{l}\text { Yes } 83.09 \% \\
\text { No } 16.91 \% \\
\text { Turnout } 70.88 \%\end{array}$ \\
\hline $\begin{array}{l}\text { Treaty on Single European } \\
\text { Act }\end{array}$ & $26^{\text {th }}$ May 1987 & $\begin{array}{l}\text { Yes } 69.92 \% \\
\text { No } 30.08 \% \\
\text { Turnout } 44.09 \%\end{array}$ \\
\hline $\begin{array}{l}\text { Treaty of European Union } \\
\text { (Maastricht) }\end{array}$ & $11^{\text {th }}$ June 1992 & $\begin{array}{l}\text { Yes } 69.05 \% \\
\text { No } 30.95 \% \\
\text { Turnout } 57.31 \%\end{array}$ \\
\hline Treaty of Amsterdam & $22^{\text {nd }}$ May 1998 & $\begin{array}{l}\text { Yes } 61.74 \% \\
\text { No } 38.26 \% \\
\text { Turnout } 56.20 \%\end{array}$ \\
\hline Nice Treaty 1 & $7^{\text {th }}$ June 2001 & $\begin{array}{l}\text { Yes } 46.13 \% \\
\text { No } 53.87 \% \\
\text { Turnout } 34.79 \%\end{array}$ \\
\hline Nice Treaty 2 & $19^{\text {th }}$ October 2002 & $\begin{array}{l}\text { Yes } 62.89 \% \\
\text { No } 37.11 \% \\
\text { Turnout } 49.47 \%\end{array}$ \\
\hline Lisbon Treaty 1 & $12^{\text {th }}$ June 2008 & $\begin{array}{l}\text { Yes } 46.60 \% \\
\text { No } 53.40 \% \\
\text { Turnout } 53.13 \%\end{array}$ \\
\hline Lisbon Treaty 2 & $2^{\text {nd }}$ October 2009 & $\begin{array}{l}\text { Yes } 67.13 \% \\
\text { No } 32.87 \% \\
\text { Turnout } 59 \%\end{array}$ \\
\hline Fiscal Treaty & $31^{\text {st }}$ May 2012 & $\begin{array}{l}\text { Yes } 60.29 \% \\
\text { No } 39.71 \% \\
\text { Turnout } 50.60 \%\end{array}$ \\
\hline
\end{tabular}

Source: Central Statistics Office (CSO) Ireland 